\title{
Quality Attributes of the Most Common Consumed Fresh Fish in Saudi Arabia
}

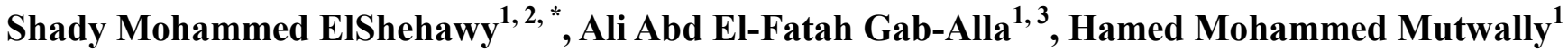 \\ ${ }^{1}$ Biology Department, Faculty of Applied Science, Umm Al-Qura University, Makkah, Saudi Arabia \\ ${ }^{2}$ Food Industries Department, Faculty of Agriculture, Mansoura University, Mansoura, Egypt \\ ${ }^{3}$ Marine Biology Department, Faculty of Science, Suez Canal University, Ismailia, Egypt
}

Email address:

yshmtu10@mans.edu.eg (Sh. M. ElShehawy), aligaballa2000@yahoo.com (A. A. Gab-Alla), pmmutwally@uqu.edu.sa (H. M. Mutwally)

\section{To cite this article:}

Shady Mohammed ElShehawy, Ali Abd El-Fatah Gab-Alla, Hamed Mohammed Mutwally. Quality Attributes of the Most Common Consumed Fresh Fish in Saudi Arabia. International Journal of Nutrition and Food Sciences. Vol. 5, No. 2, 2016, pp. 85-94.

doi: 10.11648/j.ijnfs.20160502.11

\begin{abstract}
Although fish is an important food as a source of high biological value of protein and polyunsaturated fatty acids such as EPA and DHA, fish is a fast perishable food because of the high water activity and the high enzymatic activity in fish viscera. The main target of this study was to evaluate some sensory and chemical attributes of fresh fish samples from the Central Fish Market of Makkah, Saudi Arabia. However, 33 fresh fish samples of 11 species were randomly purchased from the Central Fish Market, El-Kaakia, Makkah, Saudi Arabia during spring 2015. These species are commonly consumed by the local population in Saudi Arabia. Sensory evaluation by quality index method and some chemical analysis such as biogenic amines were done. The obtained results showed that there were significant differences between all studied fish species in $\mathrm{pH}$ and TVN value at $P>0.05$. However, there were no any significant differences in case of fish quality\%. It could be noticed that there were 8 samples from 33 samples exceeded $\mathrm{pH}$ value of 6.80 , represented $24.24 \%$ of all samples, and there were 3 samples exceeded TVN value of $30 \mathrm{mg} / 100 \mathrm{~g}$, represented $9.09 \%$ of all samples. As for quality $\%$, there were 4 samples from 33 samples below 50\%, represented $12.12 \%$ of all samples. Meanwhile, histamine content of studied fish samples ranged from $0.66 \pm 0.33 \mathrm{mg} / 100 \mathrm{~g}$ in rusty parrot fish to $17.21 \pm 2.85 \mathrm{mg} / 100 \mathrm{~g}$ in grey mullet. Eleven fish samples exceeded the permissible limit of tyramine represented $33.33 \%$. The statistical analysis showed that there were no significant differences between all studied fish samples in tyramine and phenethylamine content at $P>0.05$ with $\mathrm{F}$ value of 0.89 and 0.68 , respectively. It is recommended to carry out the same study on other central fish markets such as Jeddah, Riyadh and Dammam. Consequently, a complete quality assurance system must be planned to be applied in any central fish market in Saudi Arabia. It should be considered some criteria such as refrigerated cars, sun protected receiving area, fish layer thickness, ice/fish ratio, using of fine ice, using of salty ice and mechanical refrigeration.
\end{abstract}

Keywords: Fish Freshness, Total Volatile Nitrogen (TVN), pH Value, Biogenic Amines (BAs)

\section{Introduction}

\subsection{Fish Nutritive Value}

Fish is a food of excellent nutritional value, providing high-quality protein rich in essential amino acids, and a wide variety of minerals, including phosphorus, magnesium, iron, zinc, and iodine in marine fish. Depending on their lipid content fish are classified as lean, semi-fatty, or fatty. Fish oils of salmon, tuna, mackerel, herring and sardine are the richest source of polyunsaturated fatty acids such as eicosapentaenoic acid (C20:5, EPA) and docosahexaenoic acid (C22:6, DHA). Also, fish is generally a good source of the B vitamins and, in the case of fatty species, of A and D vitamins. Fish also has a non-protein nitrogen fraction that plays a major role in fish quality [1].

Fish is highly nutritious, tasty and easily digested. It is much sought after by a broad cross-section of the world's population, particularly in developing countries. It is estimated that around $60 \%$ of people in many developing countries depend on fish for over $30 \%$ of their animal protein supplies, while almost $80 \%$ in most developed countries obtain less than $20 \%$ of their animal protein from fish. However, with the increased awareness of the health benefits 
of eating fish and the ensuing rise in fish prices, these figures are rapidly changing [2].

\subsection{Fish World Production}

The world fishery production of fish by capture and aquaculture has been estimated as 162762416 metric tons in 2013. About $43.12 \%$ of this production was from aquaculture and the rest ratio was from capture. Saudi Arabia produced only 97348 metric tons representing $0.06 \%$ of total world production. The total Saudi Arabia imported fishery products reached about 636771 metric tons in 2012 . So, about $11.5 \mathrm{~kg}$ of fish per year was the consumed amount per capita. This ratio was very low in comparable with the world ratio $(18.9 \mathrm{~kg})[3]$.

\subsection{Fish Spoilage}

Marine species of fish are highly susceptible to rapid spoilage at ambient temperature. Preservation in ice is one of the most efficient ways of delaying spoilage. The rate of deterioration during ice storage of fish varies with species and depends on the concentrations of substrates and metabolites in the tissue, microbial contamination and conditions of storage after catching [4].

Moreover, fish is one of the most highly perishable food products and the shelf life of such products is limited in the presence of normal air by the chemical effects of atmospheric oxygen and the growth of aerobic spoilage microorganisms. The growth of microorganisms makes food organoleptically unacceptable for consumption because of changes in colour, odor and texture [5].

Immediately after capture, several chemical and biological changes take place in dead fish which can ultimately lead to rejection for human consumption because of spoilage. Fish post-harvest losses are significant, especially in developing countries. Estimated at 10 to 12 million tonnes, they account for around $10 \%$ of global capture and cultured fish. Therefore, understanding the post-harvest changes that occur in fish is very important in developing appropriate measures to reduce losses and preserve the quality and safety of the finished products [6].

\subsection{Fish Consuming in GCC}

Although the Arab Gulf Cooperation Council (GCC) countries share many similarities to developing countries in other parts of the world, they should enable the national food control systems rapidly to meet the recognized international criteria as defined by the FAO and WHO. However, financial resources need to be correctly applied and this requires effective management, which, appropriate trained and committed staff supported by the political role will ensure for all consumers a safe food supply free from fraudulent practices. The large proportion of imported food provides a key challenge to the authorities but the willingness to apply international standards should enable the GCC countries to achieve the necessary controls [7].

\subsection{Sensory Evaluation}

Sensory evaluation takes place in inspection on all levels of marketing from auction sites, processing plants, wholesale to retail level. Seafood is also inspected by sensory methods while imported. The sensory inspection is usually done by assessing appearance, texture and odour. The inspectors need professional training and retraining under supervision of experienced leaders [8].

Sensory evaluation is the most commonly used method for the quality assessment of raw fish and has always been regarded as the primary way to evaluate seafood freshness. Evaluation procedures for raw fish should be rapid, reliable, simple to apply, and specific for particular fish species. Quality Index Method (QIM) is a freshness grading system for seafood that encompasses these characteristics and is recognized as reference method in sensory research $[9,10]$.

\subsection{Chemical Criteria}

Chemical indices for freshness evaluation of fish, crustaceans and molluscs are mainly based on changes of non-protein nitrogen (NPN) components during the storage, such as volatile basic nitrogen (VBN) and trimethylamine (TMA) [11].

Total volatile bases nitrogen (TVB-N) is a general term which includes the measurement of trimethylamine (TMA), dimethylamine (DMA), ammonia, and other volatile basic nitrogenous compounds associated with seafood spoilage. The TVN value was considered as a chemical parameter frequently used as a freshness index for raw fish with satisfactory freshness should have a TVB-N $<35 \mathrm{mgN} / 100 \mathrm{~g}$. Since, the limiting quantitative content of nitrogen in the volatile bases at which fish is still regarded as whole some varies from 18 or 20 to $25 \mathrm{mg} / 100 \mathrm{~g}$ for fresh-water fish, but is up to 30 or $35 \mathrm{mg} / 100 \mathrm{~g}$ for marine fish $[12,13]$.

The $\mathrm{pH}$ value depended on fish species and was usually between 6.2 and 6.5 immediately after rigor mortis [14].

Biogenic amines (BAs), a special category of basic nitrogenous compounds with low molecular weights, are mainly formed through the microbial decarboxylation of specific free amino acids in aquatic products [15].

Because of the toxicological effects of BAs on human health, regulations and legal requirements for the maximum limits of BAs (especially for histamine HIM and tyramine TYM) in aquatic products have been suggested and established by many countries and international organizations. For example, $50 \mathrm{mg} \mathrm{kg}^{-1}$ of HIM has been suggested by the Food and Drug Administration (FDA) as a guidance level in fish [16].

Although fish has high nutritive value, it is considered as a high speed perishable food because of many reasons such as the high amount of moisture, the high activity of hydrolytic enzymes, bad handling and storage conditions and high content of unsaturated fatty acids. In addition, high temperature in Saudi Arabia and its huge wide, so there are many transportation process of fish throughout large areas for many hours in bad conditions. The quality attributes of fresh 
fish such as sensory properties and some chemical criteria could be changed, then the fish becomes unacceptable. So, the aim of this manuscript was direct to evaluate these quality attributes of fresh fish samples randomly collected from the Central Fish Market of Makkah, Saudi Arabia.

\section{Materials and Methods}

\subsection{Materials}

33 fresh fish samples of 11 species, which commonly consumed by the local population in Saudi Arabia were randomly purchased from the Central Fish Market, El-Kaakia district, Makkah, Saudi Arabia during spring 2015. They were named as follows: grey mullet Liza ramada, sabaki tilapia Oreochromis spilurus, indian oil sardine Sardinella longiceps, golden thread fin bream Nemipterus japonicas, gilt head bream Sparus aurata, asian seabass Lates calcarifer, job fish Apharus rutilanus, spangled emperor Lethrinus nebuloses, dusky grouper Epinephelus marginatus, rusty parrot fish Scarus ferrugineus and half spotted grouper Cephalopholis hemistiktos. These fish samples were collected in three batches. These samples were mixed with soft ice, put in ice box and transported to Biology department laboratory, Faculty of Applied Science, Umm Al-Qura university, Makkah, Saudi Arabia.

At first, sensory evaluation was carried out by a panel of 25 panelists using the Quality Index Method. Then, all samples were beheaded, eviscerated and filleted all manually. Muscle tissues were below the dorsal fin were taken as the samples. The fish flesh was minced. Total volatile nitrogen TVN and $\mathrm{pH}$ were determined, then fish flesh was dried at $70^{\circ} \mathrm{C}$, grinded and stored at $-18^{\circ} \mathrm{C}$ until biogenic amines analysis.

\subsection{Methods}

\subsubsection{Physical Properties}

The $\mathrm{pH}$ value was measured, as described by Lima dos Santos et al. (1981) [17], using a digital pH meter (HANNA instruments $\mathrm{pH} 211$ Microprocessor $\mathrm{pH}$ meter).

\subsubsection{Sensory Analysis}

Sensory analysis were performed by twenty five panelists. Raw fish were evaluated using the Quality Index Method (QIM) shown in Table (1). This sensory scale is based on the freshness quality grading system developed by Nielsen and Hyldig (2004) [18]. Each assessor was given simple descriptors, scoring demerit points from 0 to a maximum of 3 , where 0 represented best quality and any higher score indicated poorer quality. Panelists were asked to state whether the fish were acceptable or not.

\subsubsection{Chemical Analysis}

Total volatile nitrogen (TVN) was determined according to the method mentioned by Pearson (1968) [19]. Results were expressed as $\mathrm{mg}$ nitrogen per $100 \mathrm{~g}$ sample.

Three biogenic amines included histamine, tyramine and phenethylamine were extracted and determined in The
Central Laboratory Unit, High Institute of Public Health, Alexandria University, Egypt using HPLC as recommended by Deabes (2000) [20].

\subsubsection{Statistical Analysis}

Statistical analysis such as mean, standard error, correlation coefficient and analysis of variance (one way ANOVA) test were done using SPSS (2008) [21] version 17 program for windows.

Table 1. QIM scheme for sensory evaluation of studied fresh fish developed by Nielsen and Hyldig (2004).

\begin{tabular}{|c|c|c|}
\hline Quality parameter & \multirow[t]{2}{*}{ Description } & \multirow[t]{2}{*}{ Score } \\
\hline (1) Whole fish & & \\
\hline \multirow{3}{*}{ Appearance of skin } & Very bright & 0 \\
\hline & Bright & 1 \\
\hline & Mat & 2 \\
\hline \multirow{3}{*}{ Blood on gill cover } & None & 0 \\
\hline & Some & 1 \\
\hline & Much & 2 \\
\hline \multirow{3}{*}{ Texture } & Hard & 0 \\
\hline & Firm & 1 \\
\hline & Soft & 2 \\
\hline \multirow{3}{*}{ Texture of belly } & Firm & 0 \\
\hline & Soft & 1 \\
\hline & Burst & 2 \\
\hline \multirow{4}{*}{ Odour } & Fresh sea odour & 0 \\
\hline & Neutral & 1 \\
\hline & Slight off odour & 2 \\
\hline & Strong off odour & 3 \\
\hline (2) Eyes & & \\
\hline \multirow{2}{*}{ Appearance } & Bright & 0 \\
\hline & Somewhat lusterless & 1 \\
\hline \multirow{3}{*}{ Shape } & Convex & 0 \\
\hline & Flat & 1 \\
\hline & Sunken & 2 \\
\hline (3) Gills & & \\
\hline \multirow{2}{*}{ Colour } & Characteristics red & 0 \\
\hline & Somewhat pale, mat, brown & 1 \\
\hline \multirow{4}{*}{ Odour } & Fresh, sea weedy, metallic & 0 \\
\hline & Neutral & 1 \\
\hline & Some off odour & 2 \\
\hline & Strong off odour & 3 \\
\hline
\end{tabular}

Total demerit points (0-18).

\section{Results and Discussion}

Data in Table (2) showed mean values ( \pm standard error) of $\mathrm{pH}$, quality $\%$ and total volatile nitrogen (TVN) $\mathrm{mg} / 100 \mathrm{~g}$ of studied fish flesh samples. The $\mathrm{pH}$ values of fresh fish ranged from 5.99 in gilt head bream to 6.86 in golden thread fin bream and half spotted grouper. It was known that when $\mathrm{pH}$ 
of fresh fish is below 7, this means fish is fresh and in acceptable quality. However, it is spoiled if $\mathrm{pH}$ value is more than or going to 7 . This is because some chemical changes after death occurred and some basic products released rise $\mathrm{pH}$ value. Although all $\mathrm{pH}$ values of studied fresh fish were below 7. The $\mathrm{pH}$ value alone didn't refer to freshness. However, there were significant differences between all studied fish species in $\mathrm{pH}$ value at $P>0.05$. In other words, the $\mathrm{pH}$ value of live fish muscle tissue was close to neutrality [22]. The present findings were similar to those obtained by Pedrosa-Menabrito and Regenstein (1988) [14]. Figure (1) showed $\mathrm{pH}$ values of 33 studied fresh fish flesh samples. It could be noticed that there were 8 samples from 33 samples exceeded $\mathrm{pH}$ value of 6.80 represented $24.24 \%$ of all samples.

According to Connell (1995) [23], TVN values in freshly caught fish ranged from $5-20 \mathrm{mg} / 100 \mathrm{~g}$ and this value increased as spoilage progressed. The least TVN value recorded $12.71 \mathrm{mg} / 100 \mathrm{~g}$ in job fish sample while, the highest was $30.33 \mathrm{mg} / 100 \mathrm{~g}$ in Indian oil sardine. All studied samples were below the limit of $35 \mathrm{mg} / 100 \mathrm{~g}$ as mentioned by Zaitsev, et al. (1969) [12]. These results indicated that all studied fish samples were in acceptable quality from chemical opinion and there is no significant changes during handling. Moreover, there were significant differences between all samples in TVN at $P>0.05$. The increments of nitrogenous fractions, such as TVN value, are occurred in all handled fish because of the hydrolysis of protein by viscera and muscle enzymes and activity of microorganisms especially when these fresh fish stored in bad conditions.

These results and explanations agreed with Kapute, et al. (2012) [24] who reported that mean total volatile basic nitrogen (TVB-N), trimethylamine nitrogen (TMA-N) (mg/100g) and $\mathrm{pH}$ of Lake Malawi Tilapia fish from local and super markets were $15.40 \pm 0.00,0.10 \pm 0.01,6.11 \pm 0.12$ and $14.90 \pm 0.58,0.13 \pm 0.02,6.20 \pm 0.07$, respectively. Fish collected from local markets had significantly higher levels of TVB-N $(P<0.05)$ compared to those from super markets.
Fish from both local and super markets were contaminated generally due to poor handling by sellers but not necessarily at the selling points.

Figure (2) Showed TVN values of 33 studied fresh fish flesh samples. It could be seen that there were 3 samples from 33 samples exceeded TVN value of $30 \mathrm{mg} / 100 \mathrm{~g}$ represented $9.09 \%$ of all samples.

Quality Index Method (QIM) is an objective, rapid and reliable sensory method, based on well-defined characteristic changes that occur in the deteriorative process of seafood. QIM value is a reverse relationship with fish quality, so in this study quality \% was calculated and used as a parameter. Quality \% equal total demerit points minus the score of each fish sample divided by the total score multiply 100 .

$$
\mathrm{Q} \%=(\mathrm{TD}-\mathrm{S}) / \mathrm{TD} \times 100
$$

Results in Table (2) showed quality \% of studied fresh fish samples. Gilt head bream samples had the highest quality $\%$ of $65.04 \%$ and rusty parrot fish samples had the least value of $45.32 \%$. Rusty parrot fish samples were considered unacceptable for consumer although its $\mathrm{pH}$ and TVN were in permissible limits. There were no any significant differences between all fish samples in sensory evaluation. Figure (3) Showed quality \% values of 33 studied fresh fish samples. It could be seen that there were 4 samples from 33 samples below $50 \%$ represented $12.12 \%$ of all samples. One of rusty parrot fish samples had quality \% of 21.87 and this percentage means that this sample was spoiled and unfit for human consumption.

Although most $\mathrm{pH}$, TVN and QIM values were in permissible limit in the collected fish samples, it was noticed that the acceptability of these samples were rather low for all panelists and the authors. This note may be related to the usage of only covered cars for fish transporting to the central market without mechanical refrigerating, the large thickness of fish layer in the same box, the low ice/fish ratio used and the non-covered receiving area of central market.

Table 2. $p H$ value, quality $\%$ and total volatile nitrogen (TVN) value of studied fish flesh samples.

\begin{tabular}{|c|c|c|c|}
\hline Parameters & pH & Quality \% & TVN (mgN/100g) \\
\hline Grey mullet Liza ramada & $6.01 \pm 0.02^{\mathrm{a}}$ & $57.67 \pm 2.11^{\mathrm{a}}$ & $26.31 \pm 6.72^{\text {cd }}$ \\
\hline Sabaki tilapia Oreochromis spilurus & $6.19 \pm 0.18^{\mathrm{ab}}$ & $57.49 \pm 4.66^{\mathrm{a}}$ & $20.80 \pm 1.06^{\mathrm{abcd}}$ \\
\hline Indian oil sardine Sardinella longiceps & $6.03 \pm 0.03^{\mathrm{a}}$ & $54.57 \pm 1.14^{\mathrm{a}}$ & $30.33 \pm 2.12^{\mathrm{d}}$ \\
\hline Golden thread fin bream Nemipterus japonicas & $6.86 \pm 0.02^{\mathrm{e}}$ & $60.72 \pm 2.33^{\mathrm{a}}$ & $19.76 \pm 3.67^{\text {abcd }}$ \\
\hline Asian seabass Lates calcarifer & $6.40 \pm 0.01^{\mathrm{bc}}$ & $54.13 \pm 6.23^{\mathrm{a}}$ & $18.75 \pm 2.05^{\mathrm{abc}}$ \\
\hline Job fish Apharus rutilanus & $6.56 \pm 0.09^{\mathrm{cd}}$ & $62.02 \pm 11.29^{\mathrm{a}}$ & $12.71 \pm 3.67^{\mathrm{a}}$ \\
\hline Spangled emperor Lethrinus nebuloses & $6.62 \pm 0.08^{\text {cde }}$ & $60.22 \pm 4.95^{\mathrm{a}}$ & $24.35 \pm 2.81^{\mathrm{bcd}}$ \\
\hline Dusky grouper Epinephelus marginatus & $6.77 \pm 0.06^{\mathrm{de}}$ & $62.48 \pm 5.87^{\mathrm{a}}$ & $21.33 \pm 3.36^{\text {abcd }}$ \\
\hline Rusty parrot fish Scarus ferrugineus & $6.83 \pm 0.08^{\mathrm{e}}$ & $45.32 \pm 11.73^{\mathrm{a}}$ & $18.04 \pm 4.08^{\mathrm{abc}}$ \\
\hline F value & 21.51 & 0.79 & 2.32 \\
\hline
\end{tabular}

Mean values \pm standard error $(n=3)$. Means of samples having the same letter(s) within a column are not significantly different $(\mathrm{P}>0.05)$. 


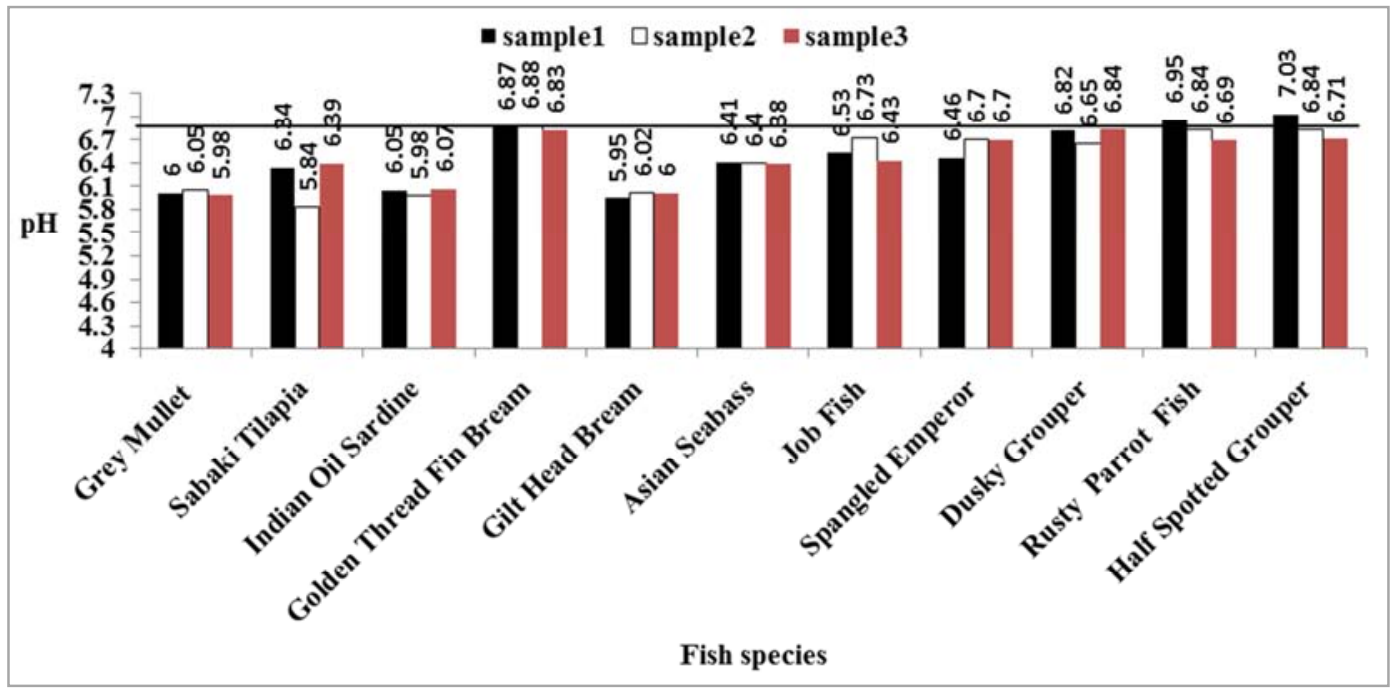

Figure 1. $p H$ value of studied fresh fish flesh samples.

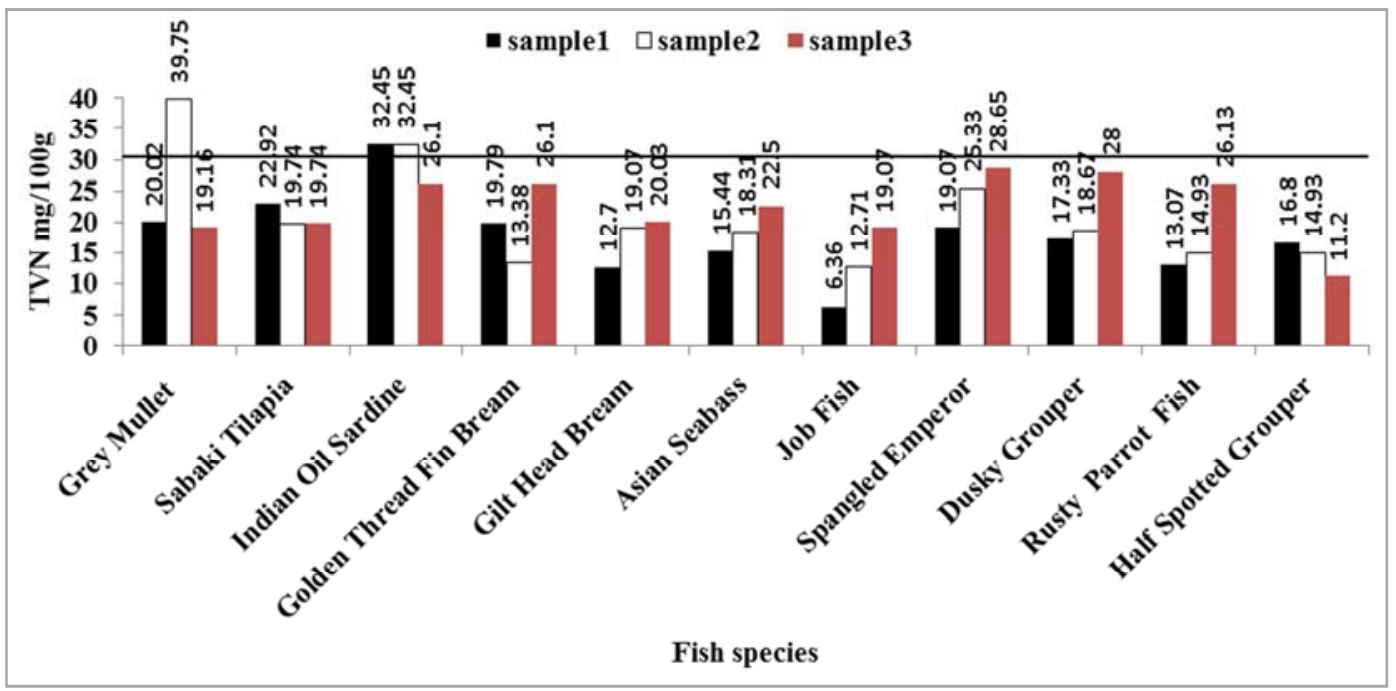

Figure 2. Total volatile nitrogen TVN content (mg/100g) of studied fresh fish flesh samples.

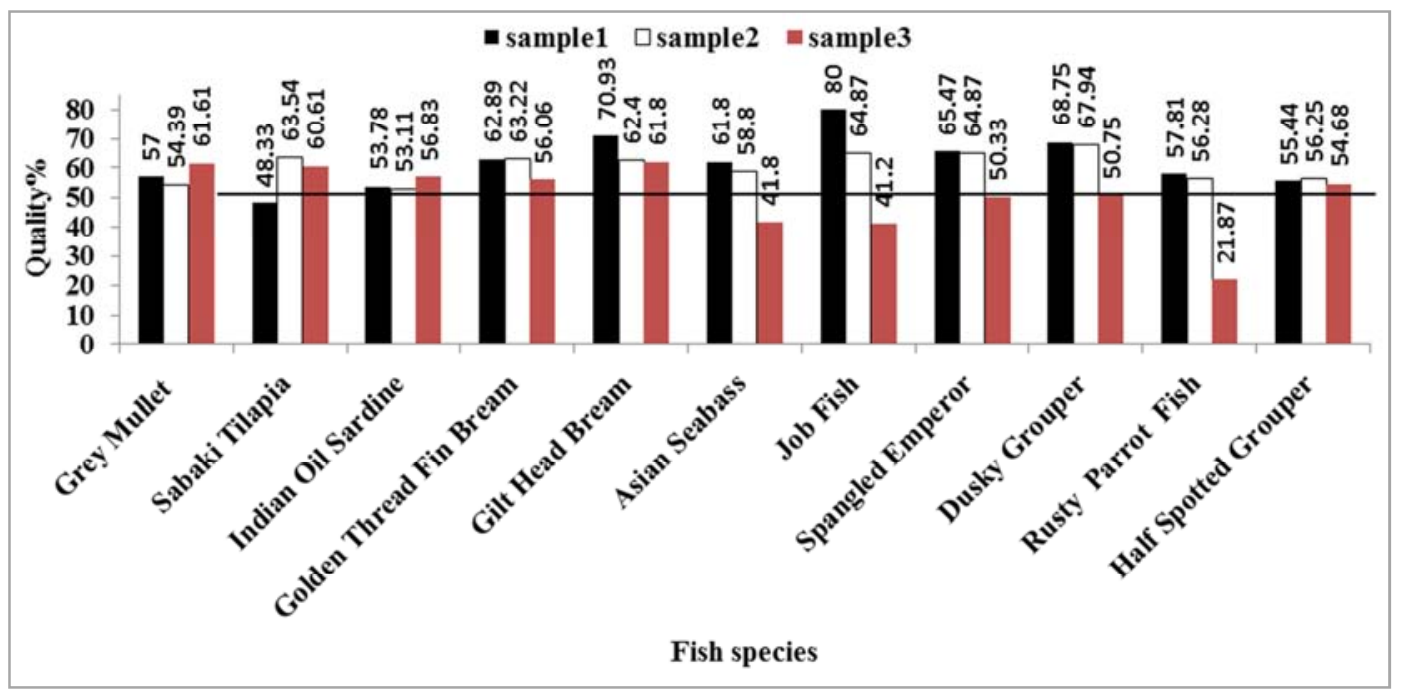

Figure 3. Quality \% of studied fresh fish flesh samples. 
Table 3. Biogenic amines content (mg/100g) of studied fish flesh samples.

\begin{tabular}{|c|c|c|c|}
\hline Biogenic amines & Histamine & Tyramine & Phenethylamine \\
\hline Grey mullet Liza ramada & $17.21 \pm 2.85^{\mathrm{a}}$ & $26.71 \pm 9.44^{\mathrm{a}}$ & $2.98 \pm 0.23^{\mathrm{a}}$ \\
\hline Sabaki tilapia Oreochromis spilurus & $5.99 \pm 2.92^{\text {bc }}$ & $18.05 \pm 13.20^{\mathrm{a}}$ & $2.41 \pm 0.37^{\mathrm{a}}$ \\
\hline Indian oil sardine Sardinella longiceps & $8.16 \pm 2.99^{b}$ & $49.86 \pm 45.02^{\mathrm{a}}$ & $2.30 \pm 0.52^{\mathrm{a}}$ \\
\hline Golden thread fin bream Nemipterus japonicas & $5.70 \pm 3.30^{\mathrm{bc}}$ & $16.90 \pm 15.13^{\mathrm{a}}$ & $1.87 \pm 0.14^{\mathrm{a}}$ \\
\hline Gilt head bream Sparus aurata & $3.23 \pm 1.83^{\mathrm{bc}}$ & $74.08 \pm 71.84^{\mathrm{a}}$ & $3.56 \pm 0.67^{\mathrm{a}}$ \\
\hline Asian seabass Lates calcarifer & $3.47 \pm 2.24^{\mathrm{bc}}$ & $4.24 \pm 1.89^{\mathrm{a}}$ & $1.54 \pm 0.64^{\mathrm{a}}$ \\
\hline Spangled emperor Lethrinus nebuloses & $2.78 \pm 1.35^{\mathrm{bc}}$ & $4.12 \pm 0.46^{\mathrm{a}}$ & $1.62 \pm 0.16^{\mathrm{a}}$ \\
\hline Dusky grouper Epinephelus marginatus & $1.43 \pm 0.20^{\mathrm{bc}}$ & $13.99 \pm 7.58^{\mathrm{a}}$ & $3.71 \pm 2.29^{\mathrm{a}}$ \\
\hline Rusty parrot fish Scarus ferrugineus & $0.66 \pm 0.33^{\mathrm{c}}$ & $1.97 \pm 1.55^{\mathrm{a}}$ & $2.38 \pm 0.45^{\mathrm{a}}$ \\
\hline Half spotted grouper Cephalopholis hemistiktos & $1.36 \pm 0.74^{\mathrm{bc}}$ & $10.63 \pm 4.91^{\mathrm{a}}$ & $1.57 \pm 0.74^{\mathrm{a}}$ \\
\hline F value & 4.82 & 0.89 & 0.68 \\
\hline
\end{tabular}

Mean values \pm standard error $(n=3)$. Means of samples having the same letter(s) within a column are not significantly different $(\mathrm{P}>0.05)$.

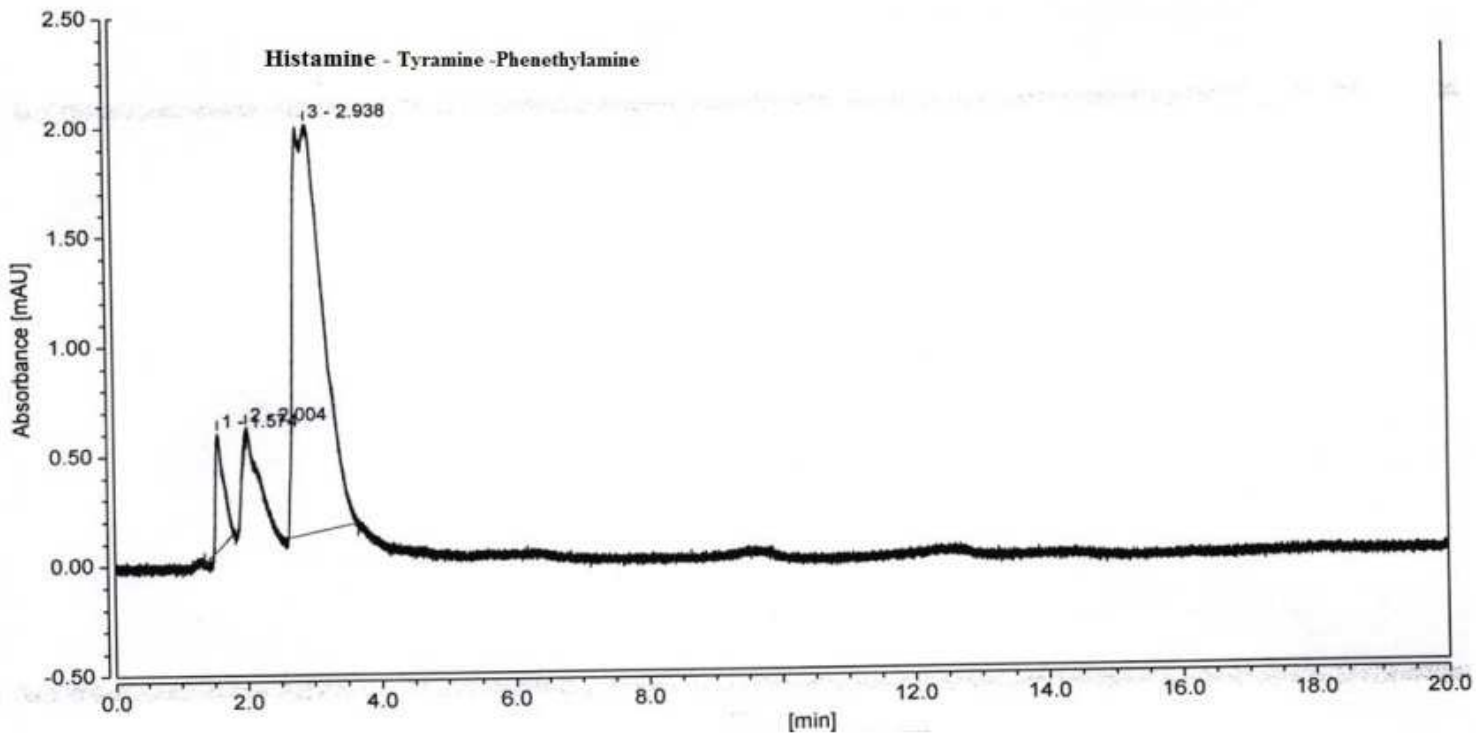

A

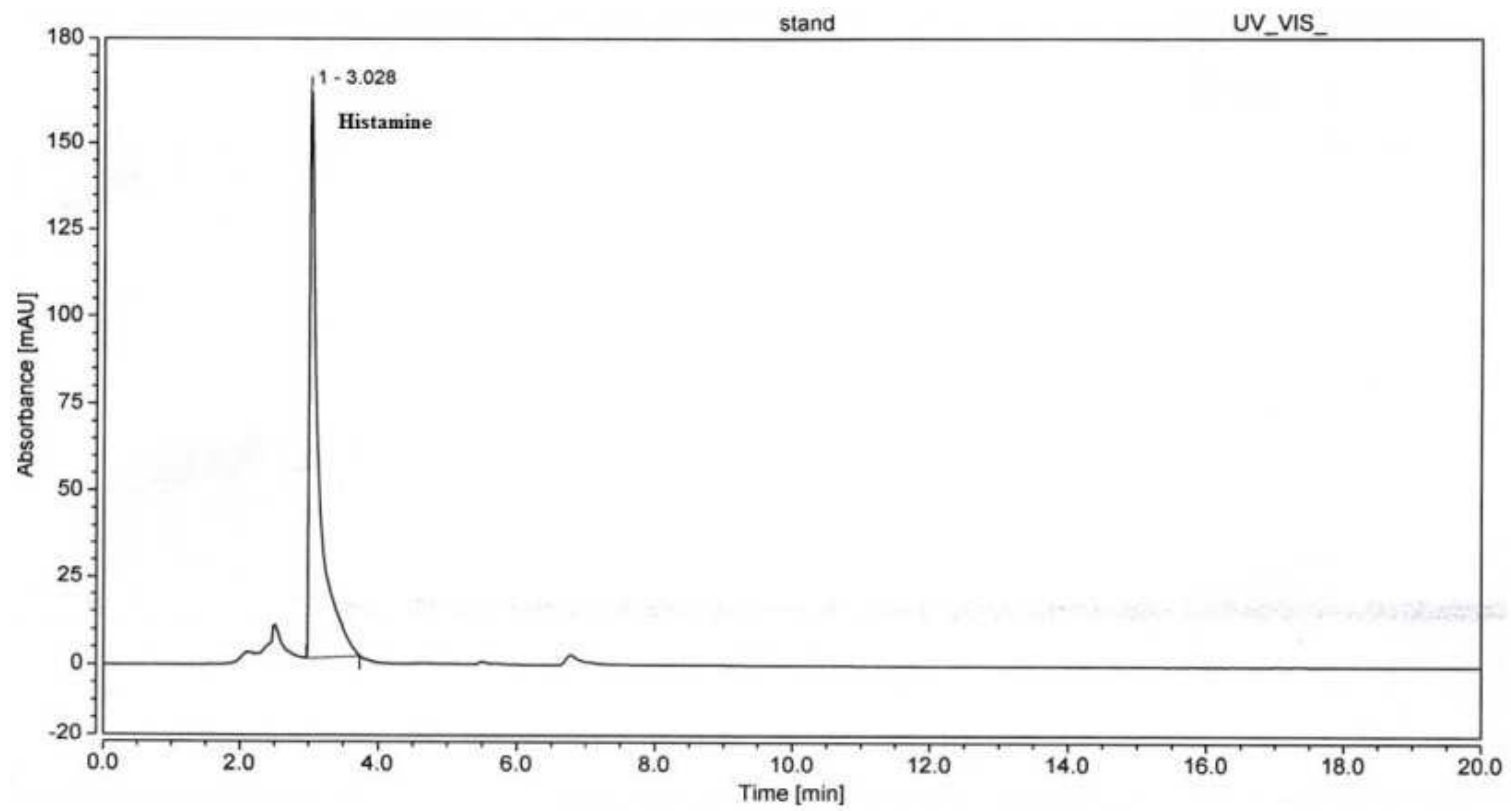




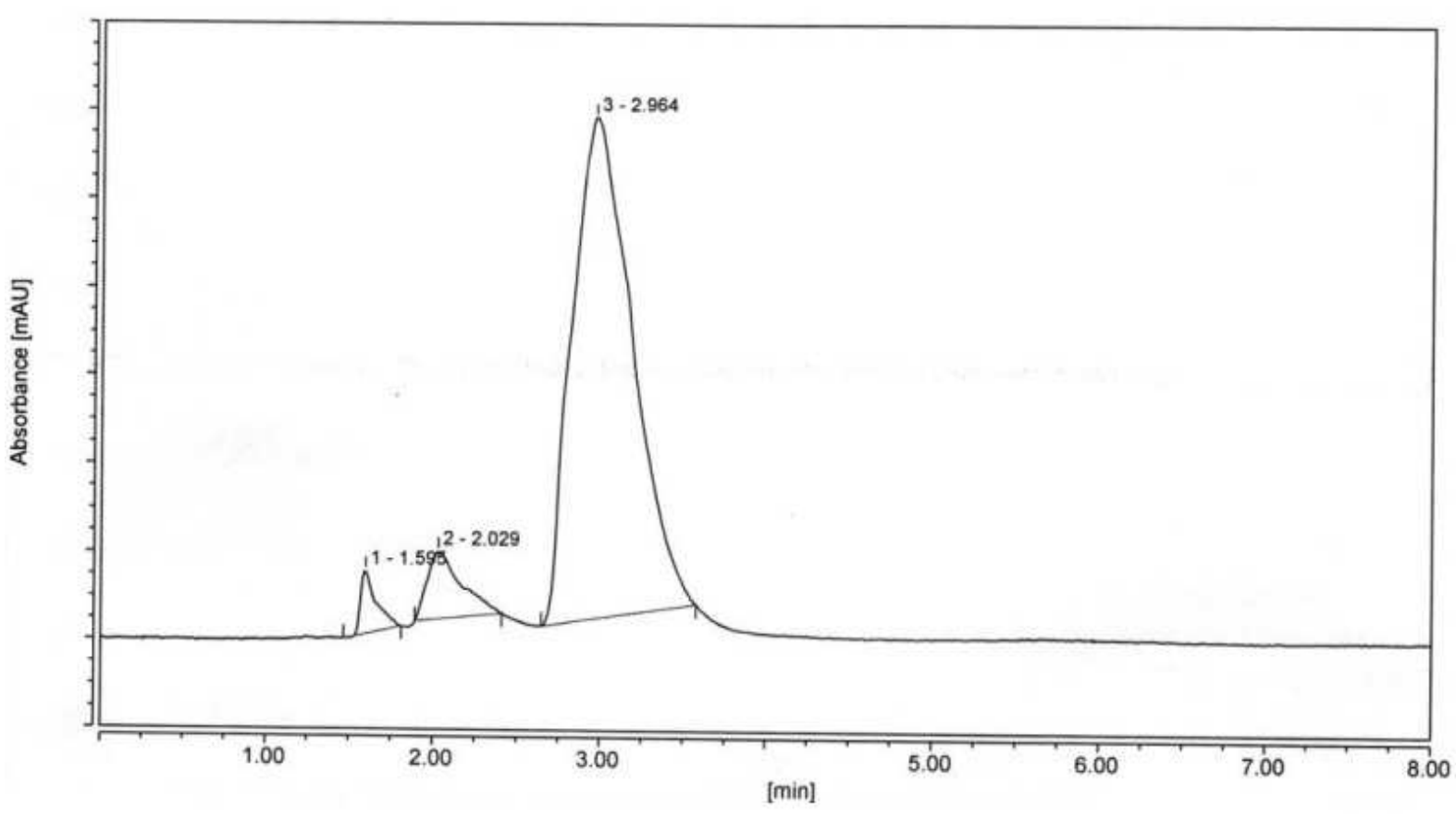

C

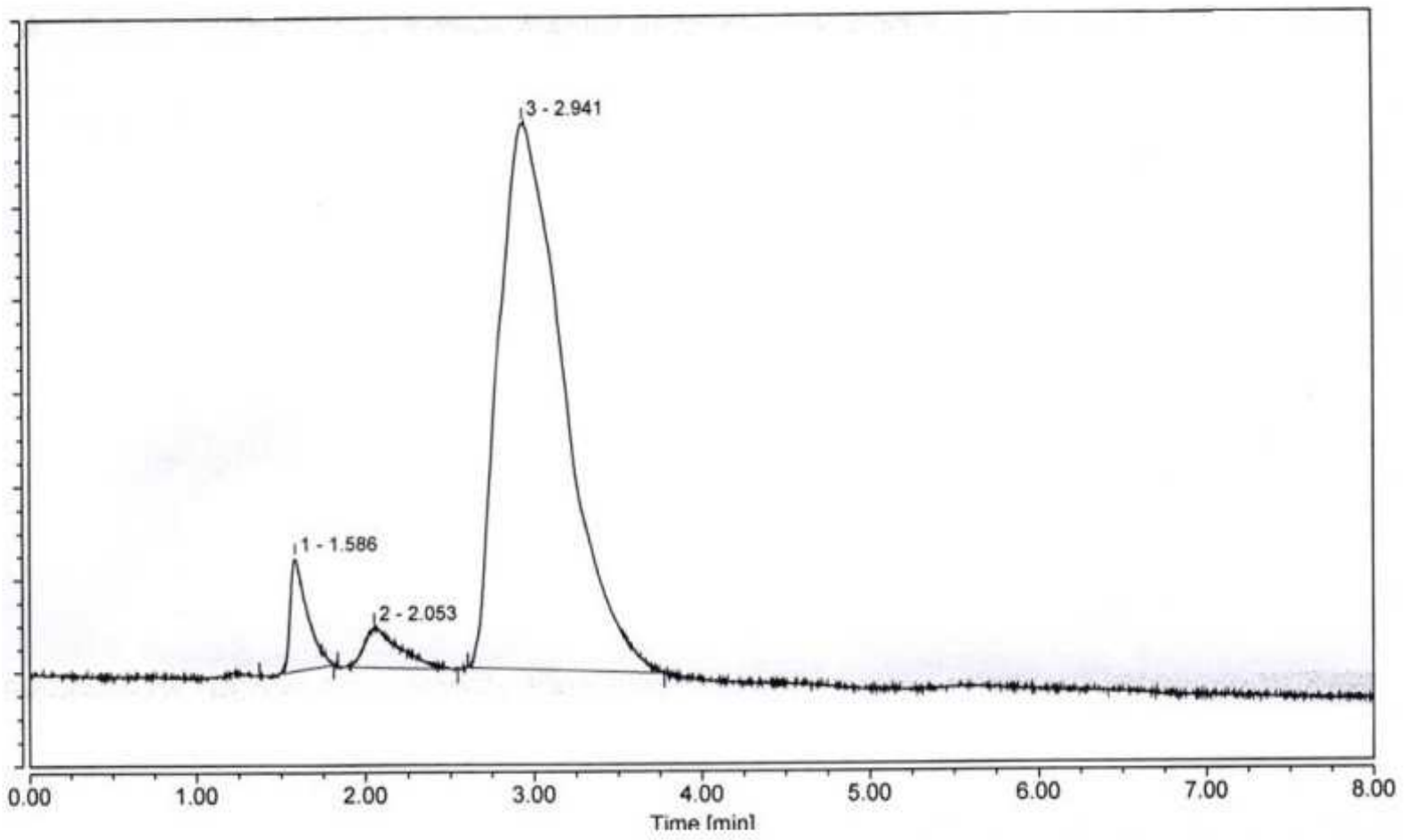

D

Figure 4. Standards and examples of biogenic amines HPLC chromatogram.

Data in Table (3) showed mean values ( \pm standard error) of some determined biogenic amines (histamine, tyramine and phenethylamine) of studied fish flesh samples. Biogenic amines (BAs) are nitrogen compounds with biological activity that are present in microorganisms, plants, and animals. They can arise from microbial activity, chemical reactions, and endogenous origin. They play important physiological functions, but at certain levels they may cause adverse toxicological effects. BAs have been found in a wide range of foods [25]. Generally, biogenic amines are indicators of animal food deterioration by microbial decarboxylation of specific free amino acids. The toxicological level of BAs is very difficult to establish because it depends on individual characteristics and the presence of other amines. However, a maximum total BAs level of $75-90 \mathrm{mg} / 100 \mathrm{~g}$ has been proposed [26]. Histamine is a biogenic amines resulted from microbial decarboxylation of histidine. Histamine content ranged from $0.66 \mathrm{mg} / 100 \mathrm{~g}$ in 
rusty parrot fish to $17.21 \mathrm{mg} / 100 \mathrm{~g}$ in grey mullet. Grey mullet sample exceeded the permissible limit of histamine (10mg/100g) according to the EU Regulation No. 2073/2005 (EU, 2005) [27]. There were significant differences between all studied samples at $P>0.05$ with $\mathrm{F}$ value of 4.82 .

Figure (4) showed standards and examples of biogenic amines HPLC chromatogram. Figure (4-A) showed standard HPLC chromatogram of the three determined biogenic amines (histamine, tyramine and phenethylamine). The data in Figure (4-A, B) revealed that retention time of histamine was $3.928 \mathrm{~min}$., retention time of tyramine was $2.004 \mathrm{~min}$. and retention time of phenethylamine was $1.574 \mathrm{~min}$. Figure (4-C, D) showed examples of HPLC chromatogram for some fish flesh samples.

Figure (5) showed histamine content $(\mathrm{mg} / 100 \mathrm{~g})$ of 33 studied fish flesh samples. It could be reported that 6 samples of 33 samples exceeded $10 \mathrm{mg} / 100 \mathrm{~g}$ represented $18.18 \%$. Histamine content of the three grey mullet samples was more than the permissible limit. This is because grey mullet and sabaki tilapia were aquaculture fish, while the rest of studied fish were wild marine fish.

Tyramine is a naturally occurring monoamine compound and trace amine derived from the amino acid tyrosine. The least tyramine content was found in rusty parrot fish sample $(1.97 \mathrm{mg} / 100 \mathrm{~g})$, while the highest tyramine content was found in gilt head bream $(74.08 \mathrm{mg} / 100 \mathrm{~g})$. This high standard error (71.84) was caused by the high content of tyramine of a fish sample recorded $145.92 \mathrm{mg} / 100 \mathrm{~g}$. All studied fish sample didn't show any significant differences at $P>0.05$ with F value of 0.89 . Tyramine content of all studied fish samples $(\mathrm{mg} / 100 \mathrm{~g})$ was shown in Figure (6). It could be seen that eleven fish samples exceeded the permissible limit of tyramine represented $30.30 \%$.

Phenethylamine (PEA), also known as $\beta$-phenylethylamine ( $\beta$-PEA) and 2-phenylethylamine is an organic compound and a natural monoamine alkaloid, a trace amine, and also the name of a class of chemicals with many members that are well known for their psychoactive and stimulant effects. Results in Table (2) showed mean ( \pm standard error) of phenethylamine content $(\mathrm{mg} / 100 \mathrm{~g})$ in the studied fish flesh samples. The tabulated results showed the highest value of phenethylamine found in job fish samples $(16.07 \mathrm{mg} / 100 \mathrm{~g})$, while the least value was found in Asian seabass sample $(1.54 \mathrm{mg} / 100 \mathrm{~g})$. The statistical analysis showed that there were no significant differences between all studied fish samples at $P>0.05$ with $\mathrm{F}$ value of 0.68 .

Phenethylamine content $(\mathrm{mg} / 100 \mathrm{~g})$ of 33 fish flesh samples was illustrated in Figure (7). Only one fish flesh sample exceeded $10 \mathrm{mg} / 100 \mathrm{~g}$ of phenethylamine named job fish and recorded $46.6 \mathrm{mg} / 100 \mathrm{~g}$.

Although one of rusty parrot fish samples had $\mathrm{pH}$, TVN and biogenic amines below the permissible limits for each, it had the least value of quality $\%$ and was unacceptable. This note may be attributed to its low content of specific free amino acids or loss of some chemical components in drip during ice chilling.

The statistical analysis showed medium positive correlation between TVN content and histamine content recorded 0.504 with highly significant differences at $P>0.01$. Correlation coefficient between quality $\%$ and TVN content and $\mathrm{pH}$ was negatively weak $(-0.136,-0.074)$, respectively.

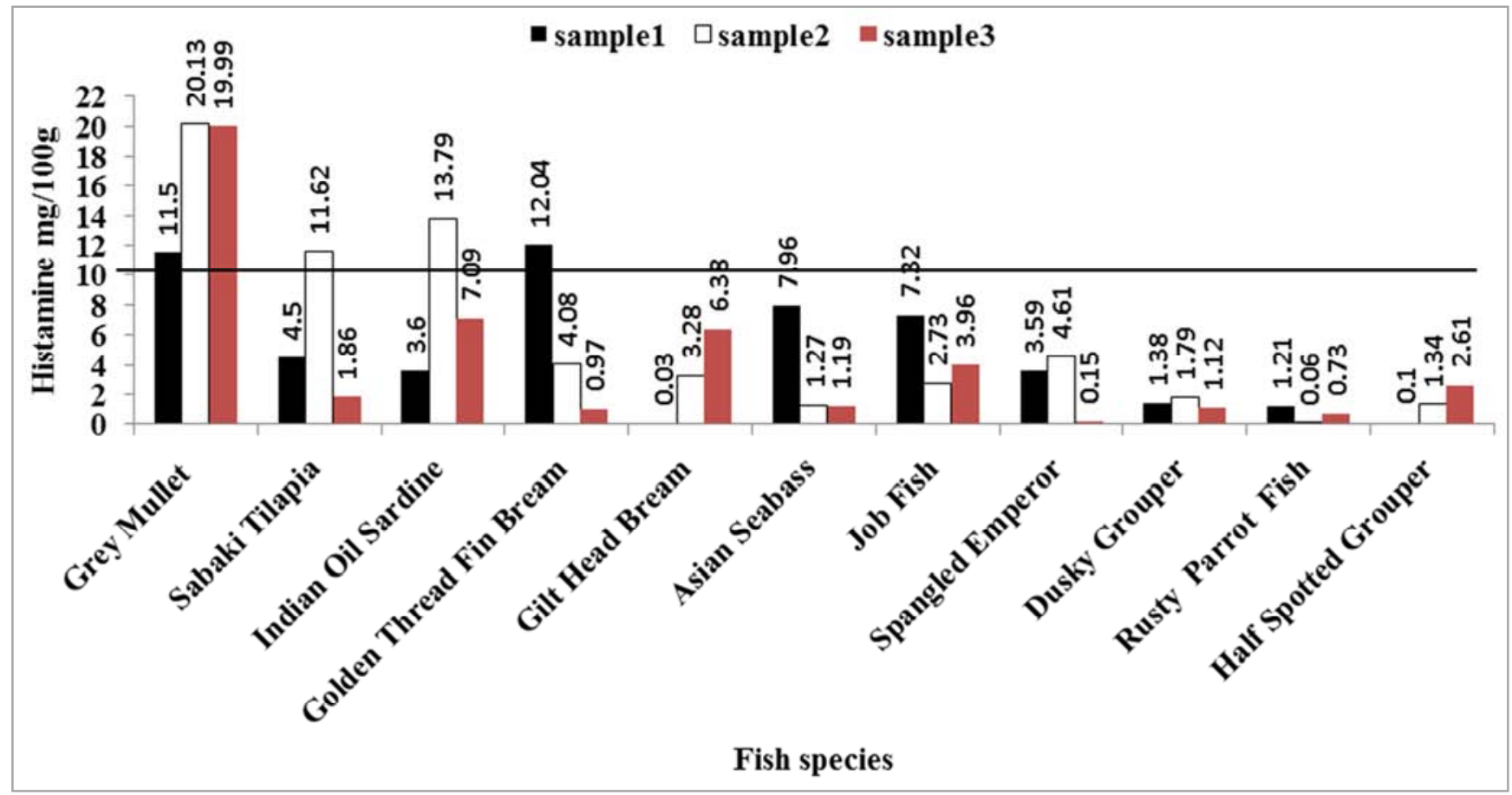

Figure 5. Histamine content ( $\mathrm{mg} / 100 \mathrm{~g})$ of studied fish flesh samples. 


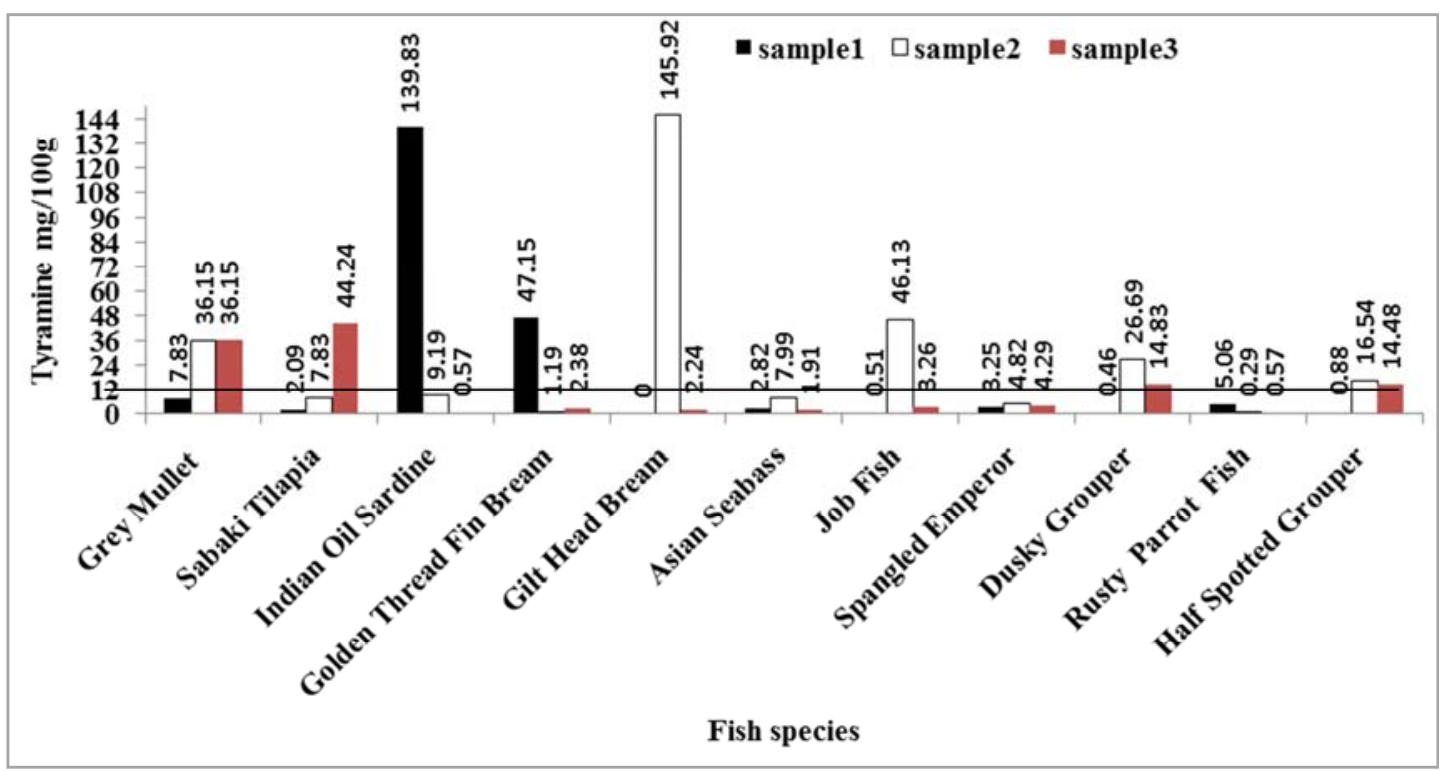

Figure 6. Tyramine content (mg/100g) of studied fish flesh samples.

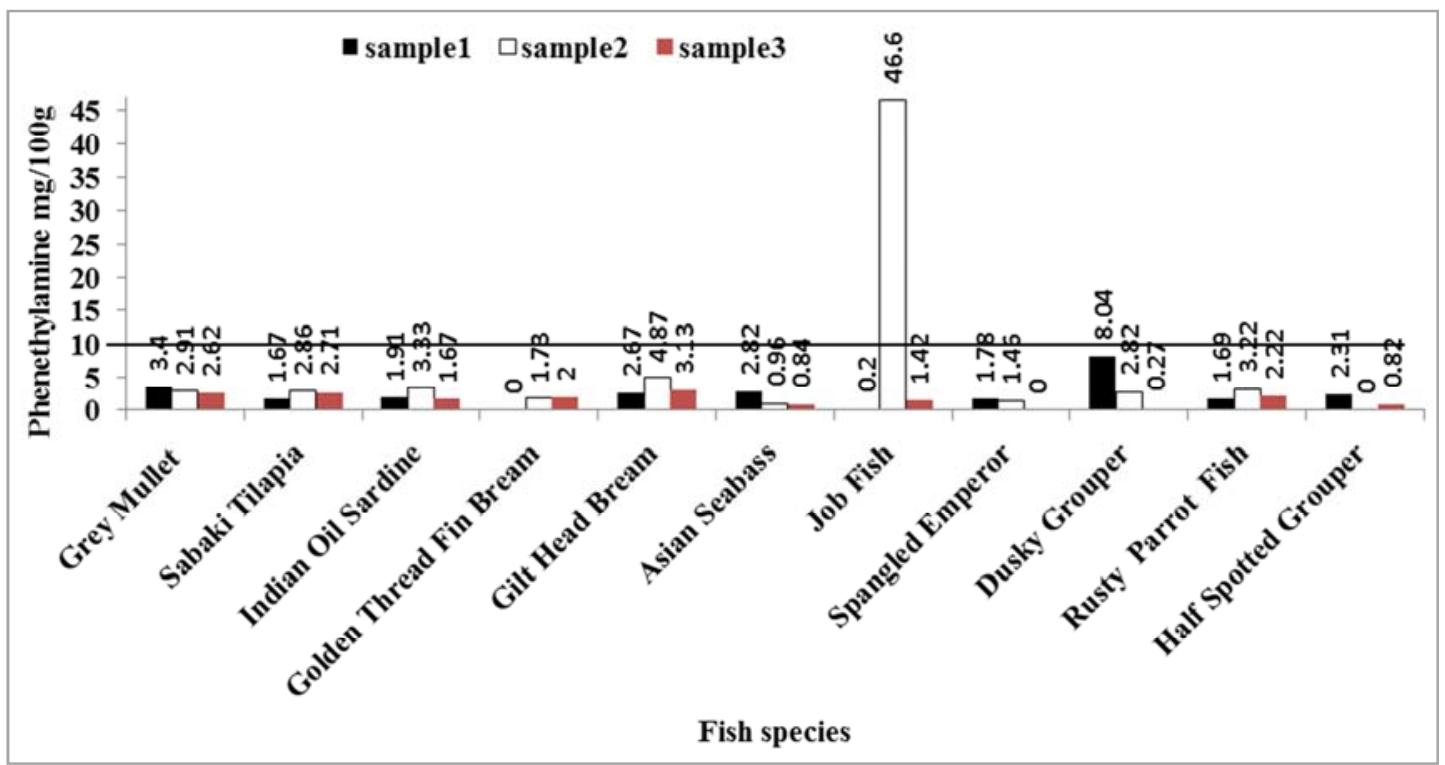

Figure 7. Phenethylamine content (mg/100g) of studied fish flesh samples.

\section{Conclusion}

It could be concluded from the results of this study that most fish samples were acceptable for costumers according to sensory and chemical evaluation. Whereas, some fish samples were unacceptable such as rusty parrot fish (sample 3), although $\mathrm{pH}$ and TVN values were below the permissible limits. There were some defects in fresh fish handling process (fresh fish chain) in Saudi Arabia generally and especially in Makkah. That's because of the weather (temperature), country nature (long roads) and bad conditions of transportation, so the time from fish catching to reaching the central market takes too long time to keep and save fish in high quality. This study recommend at first to carry out the same procedure and method on other central markets in Saudi Arabia such as Jeddah, Riyadh and Dammam.
Consequently, a complete quality assurance system must be planned to apply in any fish central market in Saudi Arabia to produce safe and high quality fresh fish for Saudi costumers.

\section{Acknowledgments}

The authors would like to thank Institute of Scientific Research and Revival of Islamic Heritage at Umm Al-Qura University (Project ID 43405028) for the financial support.

\section{References}

[1] Ariño, A.; Beltrán, J. A.; Herrera, A. and Roncalés, P. (2013). Fish and Seafood: Nutritional Value. Reference Module in Biomedical Sciences, from Encyclopedia of Human Nutrition (Third Edition), Pp: 254-261. 
[2] FAO $\left(2013^{a}\right)$. Nutritional elements of fish. Fisheries and Aquaculture Department, Food and Agriculture Organization of the United Nations. http://www.fao.org/fishery/topic/12319/en

[3] FAO (2015). Fisheries Department Statistical Databases and software.

http://www.fao.org;ftp://ftp.fao.org/fi/stat/summary/default.htm

[4] Pacheco-Aguilar, R.; Lugo-Sanchez, M. E. and RoblesBurgueno, M. R. (2000). Postmortem biochemical and functional characteristic of Monterey sardine muscle stored at $0^{\circ} \mathrm{C}$. Journal of Food Science, 65: 40-47.

[5] Özogul, F.; Polaa, A. and Özogul, Y. (2004). The effects of modified atmosphere packaging and vacuum packaging on chemical, sensory and microbiological changes of sardines (Sardina pilchardus). Food Chemistry, 85: 49-57.

[6] FAO $\left(2013^{\mathrm{b}}\right)$. Post-harvest changes in fish. Fisheries and Aquaculture Department, Food and Agriculture Organization of the United Nations. http://www.fao.org/fishery/topic/12320/en

[7] Al-Kandari, D. and Jukes, D. J. (2009). A situation analysis of the food control systems in Arab Gulf Cooperation Council (GCC) countries. Food control, 20: 1112-1118.

[8] Oehlenschläger, J. (1997). Sensory evaluation in inspection. In: Olafsdóttir, G.; Luten, J.; Dalgaard, P.; Careche, M.; Verrez-Bagnis, E.; Martinsdótirr; E. and Heia, K. Eds. Methods to Determine the Freshness of Fish in Research and Industry. Proceedings of the Final Meeting of the Concerted Action Evaluation of Fish Freshness. Paris: International Institute of Refrigeration pp. 339-334.

[9] Olafsdottir, G.; Martinsdottir, E.; Oehlenschlager, J.; Dalgaard, P.; Jensen, B.; Undeland, I.; Mackie, I. M.; Henehan, G.; Nielsen, J. and Nilsen, H. (1997). Methods to evaluate fish freshness in research and industry. Trends Food Sci. Tech., 8: 258-265.

[10] Martinsdottir, E.; Sveinsdottir, K.; Luten, J. B.; Schelvis-Smit, R. and Hyldig, G. (2001). Sensory Evaluation of Fish Freshness. Reference Manual for the Fish Sector. Ijmuiden: QIM-Eurofish.

[11] Lapa-Guimaraes, J.; de Felicio, P. E. and Contreras, E. S. G. (2005). Chemical and microbial analyses of squid muscle (Loligo plei) during storage in ice. Food Chemistry, 91(3): 477-483.

[12] Zaitsev, V.; Kizevetter, I.; Langunov, L.; Mokarova, T.; Minoler, L. and Podsevalov, V. (1969). Fish Curing and Processing. Mir publisher, Moscow.

[13] Sallam, Kh. I.; Ahmed, A. M.; Elgazzar, M. M. and Eldaly, E. A. (2007). Chemical quality and sensory attributes of marinated Pacific saury (Cololabis saira) during vacuumpackaged storage at $4^{\circ} \mathrm{C}$. Food Chemistry, 102: 1061-1070.
[14] Pedrosa-Menabrito, A. and Regenstein, J. M.(1988). Shelf-life extension of fresh-fish spoilage of fish. Journal of Food Quality, 11: 117-127.

[15] Chong, C. Y.; Abu Bakar, F.; Russly, A. R.; Jamilah, B. and Mahyudin, N. A. (2011). The effects of food processing on biogenic amines formation. International Food Research Journal, 18(3): 867-876.

[16] FDA (1996). Decomposition and histamine in raw, frozen tuna and mahi-mahi, canned tuna and related species. Compliance Policy Guide. 7108.240.

[17] Lima Dos Santos, C.; James, D. and Teutscher, F. (1981). Guidelines for chilled fish storage experiments. FAO Fisheries Technical Paper 210.

[18] Nielsen, D. and Hyldig, G. (2004). Influence of handling procedures and biological factors on the QIM evaluation of whole herring (Clupea harengus L.). Food Research International, 37: 975-983.

[19] Pearson, D. (1968). Application of chemical methods for the assessment of beef quality. II: Methods related to protein breakdown. Journal of food Science and Agriculture, 19(7): 366.

[20] Deabes, M. M. (2000). Studies on some biogenic amines in some meat and fish products with respect to other quality attributes. M. Sc. Thesis, Food Science and Technology Dept., Faculty of Agriculture, Al-Azhar Univ., Cairo, Egypt.

[21] SPSS, (2008). Statistical Package for Social Sciences Program, Version 17 for Windows, SPSS Inc, Chicago, IL, USA.

[22] Huss, H. H. (1995). Quality and Quality changes in Fresh Fish. FAO Fisheries Technical Paper 348: FAO, United Nations, Rome.

[23] Connell, J. J. (1995). Control of Fish Quality-Proposed Limit of Acceptability for Marine Species. Fishing News Ltd., Surrey, England, 179pp.

[24] Kapute, F.; Likongwe, J.; Kang'ombe, J.; Kiiyukia, C. and Mpeketula, P. (2012). Quality Assessment of Fresh Lake Malawi Tilapia (Chambo) Collected from Selected Local and Super Markets in Malawi. Internet Journal of Food Safety, 14: 113-121.

[25] Nuñez M.; Olmo, A. and Calzada, J. (2016). Biogenic amines. Reference Module in Food Science, from Encyclopedia of Food and Health, Pp: 416-423.

[26] Ladero, V.; Calles-Enriquez, M.; Fernandez, M. and Alvarez, M. A. (2010). Toxicological effects of dietary biogenic amines. Curr. Nutr. Food Sci., 6: 145-156.

[27] EU (2005). Commission Regulation (EC) No 2073/2005 on microbiological criteria for foodstuffs. Official Journal of the European Union. L338/1. 